\title{
OPEN Diverse activities and biochemical properties of amylase and proteases from six freshwater fish species
}

\author{
Chamaiporn Champasri ${ }^{\bowtie}$, Suthathip Phetlum \& Chanakan Pornchoo
}

This study investigated the biochemical properties, enzyme activities, isoenzyme pattern, and molecular weight of three types of digestive enzyme from six freshwater fish species: Puntius gonionotus (common silver barb), Puntioplites proctozysron (Smith's barb), Oreochromis niloticus (Nile tilapia), Hemibagrus spilopterus (yellow mystus), Ompok bimaculatus (butter catfish), and Kryptopterus geminus (sheatfish). The optimum $\mathrm{pHs}$ for amylase and alkaline protease activities were 7.0-8.0 and 8.0-10.0, and the optimum temperatures were $45-60^{\circ} \mathrm{C}$ and $50-55^{\circ} \mathrm{C}$, respectively. A pepsin-like enzyme was detected in all three carnivorous fishes (Ompok bimaculatus, Kryptopterus geminus, and Hemibagrus spilopterus) with optimum reaction $\mathrm{pH}$ of 2.0 for each and optimum reaction temperatures $50-55^{\circ} \mathrm{C}$. In optimum reaction conditions, the amylase and alkaline protease from Puntioplites proctozyron showed the highest activities. Lower activities of all enzymes were observed at temperature $\left(29^{\circ} \mathrm{C}\right)$ of Lam Nam Choen swamp than at the optimum reaction temperatures. The fish species contained one to three and five to eight isoforms of amylase and alkaline protease, respectively, with molecular weights from 19.5 to $175 \mathrm{kDa}$. Both the alkaline proteases and amylases were stable in wide $\mathrm{pH}$ and temperature ranges.

Amylase and protease are important enzymes in cellular metabolism in plants, animals, and microorganisms. Both enzymes function to catalyze degradation of macromolecules into small building blocks, which are subsequently used to produce energy or to synthesize other biomolecules inside cells. Extracellular digestive enzymes present in the digestive tract of animals or in the digestive system of carnivorous or insectivorous plants ${ }^{1,2}$ also have a crucial role in digestion of macromolecules from food.

Proteases catalyze the breakdown of proteins into small peptides and amino acids. They are found in all living organisms. Based on the optimum $\mathrm{pH}$ for enzymatic activity, these enzymes are classified into two groups-acidic and alkaline proteases. The former enzymes, such as pepsin, function in acidic conditions with optimum $\mathrm{pH}$ around 2.0-4.0 and are mostly found in the stomach of humans and animals. Alkaline proteases are present in the small intestine of humans and the digestive system of animals. This group includes chymotrypsin and trypsin, which have optimum reaction $\mathrm{pH}$ values ranging from 8.0 to 12.5 .

Amylases catalyze the hydrolysis of polysaccharides such as starch and glycogen into short-chain sugars. These enzymes are ubiquitous and play an important metabolic role. According to catalytic function and enzyme structure, amylases are classified into three types: $\alpha$-amylase (EC 3.2.1.1), $\beta$-amylase (EC 3.2.1.2), and $\gamma$-amylase (EC 3.2.1.3). $\alpha$-Amylase is a metalloenzyme requiring calcium ions for catalytic function. This enzyme randomly hydrolyzes $\alpha$-1,4-glycosidic bonds, releasing maltose and glucose ${ }^{3} . \beta$-Amylase is a calcium-independent enzyme that catalyzes the hydrolysis of $\alpha$-1,4-glycosidic linkages at the nonreducing end of starch molecules, yielding a maltose unit. $\gamma$-Amylase catalyzes the hydrolysis of the last $\alpha$-1,4-glycosidic bond at the nonreducing end of starch yielding one glucose unit; $\gamma$-amylase is mostly active in acidic conditions.

Due to the rapid growth of microorganisms, which enables high-yield enzyme production, microbial enzymes are widely used in various industries such as the manufacture of detergent, paper and pulp, textiles, and food and animal feed ${ }^{4}$. Nevertheless, there are drawbacks of some bacterial enzymes, such as low stability at high temperature (except for thermophilic bacteria) or a narrow $\mathrm{pH}$ range for activity. Therefore, novel enzymes with high activity and high stability at broad ranges of $\mathrm{pH}$ and temperature are still required for a wide range of uses. Studies of protease and amylase have been reported in plants ${ }^{5-7}$, insects ${ }^{8,9}$, microorganisms $s^{10,11}$ and fish ${ }^{12-18}$. The 


\begin{tabular}{|l|l|l|l|l|}
\hline Fish species & Body length $\mathbf{( c m )}$ & Body weight $\mathbf{( g )}$ & Digestive tract weight $(\mathbf{g})$ & DSI \\
\hline Ompok bimaculatus & $19.30 \pm 1.8$ & $55.02 \pm 4.1$ & $1.44 \pm 0.3$ & $2.73 \pm 0.6$ \\
\hline Kryptopterus geminus & $14.58 \pm 0.60$ & $17.10 \pm 1.75$ & $0.43 \pm 0.08$ & $2.53 \pm 0.53$ \\
\hline Hemibagrus spilopterus & $21.20 \pm 1.29$ & $73.86 \pm 6.43$ & $3.88 \pm 1.24$ & $3.44 \pm 1.04$ \\
\hline Puntius gonionotus & $15.15 \pm 1.6$ & $48.84 \pm 13.9$ & $3.65 \pm 1.1$ & $7.06 \pm 0.2$ \\
\hline Oreochromis niloticus & $23.08 \pm 3.2$ & $203.47 \pm 62.6$ & $11.13 \pm 1.4$ & $6.46 \pm 1.8$ \\
\hline Puntioplites proctozysron & $13.08 \pm 1.67$ & $31.63 \pm 14.69$ & $0.97 \pm 0.28$ & $3.07 \pm 1.33$ \\
\hline
\end{tabular}

Table 1. Data of body length, body weight, digestive tract weight, and calculated digestive somatic index of fishes. Values are mean \pm SEM of five to eight specimens of each fish species.

data report various enzyme activities, biochemical properties, and molecular weights of amylase and protease. The optimum $\mathrm{pH}$ values for catalytic activity of acidic proteases, alkaline protease, and amylase are in the range 2.5-3.0, 7.5-12.5 and 7.0-9.0 respectively, and the optimum temperature varies between 25 and $70^{\circ} \mathrm{C}$. Molecular weights range from 18 to $101 \mathrm{kDa}$ and 18 to $139.5 \mathrm{kDa}$ for protease and amylase, respectively. The number of isoenzymes (the enzymes differ in amino acid sequences and molecular sizes but catalyze the same reaction) varies from one to eight, dependent on the species from which the enzymes are derived. Noticeably, almost all bacteria and plants contain only one isoform of amylase and protease, but fishes and shrimps contain many isoforms. In addition, different species have isoenzymes of different molecular weight ${ }^{16,19}$. However, almost all recently available data on fish digestive enzymes are from omnivorous fish. Little information has been reported about these enzymes in carnivorous or herbivorous fish.

Cyprinidae, Siluridae, Bagridae, and Cichlidae are fish families widely distributed in North America, Africa, and Southeast Asia ${ }^{20}$. Puntius gonionotus (common silver barb) and Puntioplites proctozysron (Smith's barb) belong to the Cyprinidae; Ompok bimaculatus (butter catfish) and Kryptopterus geminus (sheatfish) belong to the Siluridae; Hemibagrus spilopterus (yellow mystus) belongs to the Bagridae; and Oreochromis niloticus (Nile tilapia) belongs to the Cichlidae. All six species are important for food, and economically. The types and number of fish species in a locality depend on various factors such as the abundance of the ecosystem and the local management of water resources. The growth rate of each fish species affects the abundance and fish diversity.

Little is known on the digestive systems of freshwater fishes, therefore this study aimed to investigate the biochemical properties of digestive enzymes-amylase and protease-from six freshwater fish species. The enzyme activities in optimum and environmental conditions were determined and compared. Moreover, the isoenzyme patterns and their molecular weights, as well as the enzyme stabilities, were analyzed. This study will help understanding of the digestive enzymes of each fish species, not only for sustainable fish management, but also for improvement of fish feed formula, in order to increase the growth rate of fish and reduce feed cost and cultivation time in aquaculture.

\section{Results}

Fish samples. Carnivorous fishes Om. bimaculatus, K. geminus, H. spilopterus; herbivorous fishes Puntius gonionotus and Puntioplites proctozysron; and omnivorous fish Or. niloticus were selected for this study. Details of body length, body weight, digestive tract weight, and calculated digestive somatic index (DSI) values are indicated in Table 1. A high DSI value indicates high digestive capability. P. gonionotus, Or. niloticus, and $P$. proctozysron exhibited high digestive enzyme activity; the two former species displayed a high DSI value, but the latter did not.

Optimum pH and temperature for enzyme activity. Time course assays showed a linear relationship between enzyme activity and incubation time when using 20 or $25 \mu \mathrm{l}$ of crude enzyme preparation containing mixtures of isoenzymes extracted from the digestive tract of each fish species for the detection of amylase or protease activity (data not shown). Therefore, an incubation time between 5 and $20 \mathrm{~min}$ was chosen for testing enzyme activity. The enzymes from the different fish species showed various optimum $\mathrm{pHs}$ and temperatures for enzymatic activity. Almost all of the amylases showed the same optimum $\mathrm{pH}$ for activity, $\mathrm{pH}$ 8.0, except for K. geminus amylase, for which the optimum $\mathrm{pH}$ was 7.0 (Fig. 1a). The maximum alkaline protease activity was observed at different $\mathrm{pH}$ values for the enzymes from different fishes (Fig. 1c).

The optimum temperatures for enzyme activity in this study were in the range $45-60{ }^{\circ} \mathrm{C}, 50-55^{\circ} \mathrm{C}$, and $50-55^{\circ} \mathrm{C}$ for amylase, alkaline protease, and pepsin-like enzyme, respectively (Fig. 1b,d,e). No correlation between fish families and optimum temperature for enzyme activity was observed. Interestingly, we found thermostable enzymes in P. gonionotus and P. proctozysron. Both amylases and alkaline proteases from these fish showed high activities in a broad temperature range, particularly the alkaline proteases, whose activities were $>84 \%$ at 35 to $60{ }^{\circ} \mathrm{C}$ compared with the maximum activity at the optimum temperature (defined as $100 \%$ activity). This result suggests that these enzymes are potential candidates for use in broad applications.

Comparison of enzyme activity. Study of enzyme activity at different temperatures helps us to understand food digestion capacity of fishes. Fish are cold-blooded-their temperature depends on the water temperature. However, determination of digestive enzyme activity at the water temperature of the swamp, pond, or aquarium has rarely been reported. In this study, digestive enzyme activities determined in optimum and 

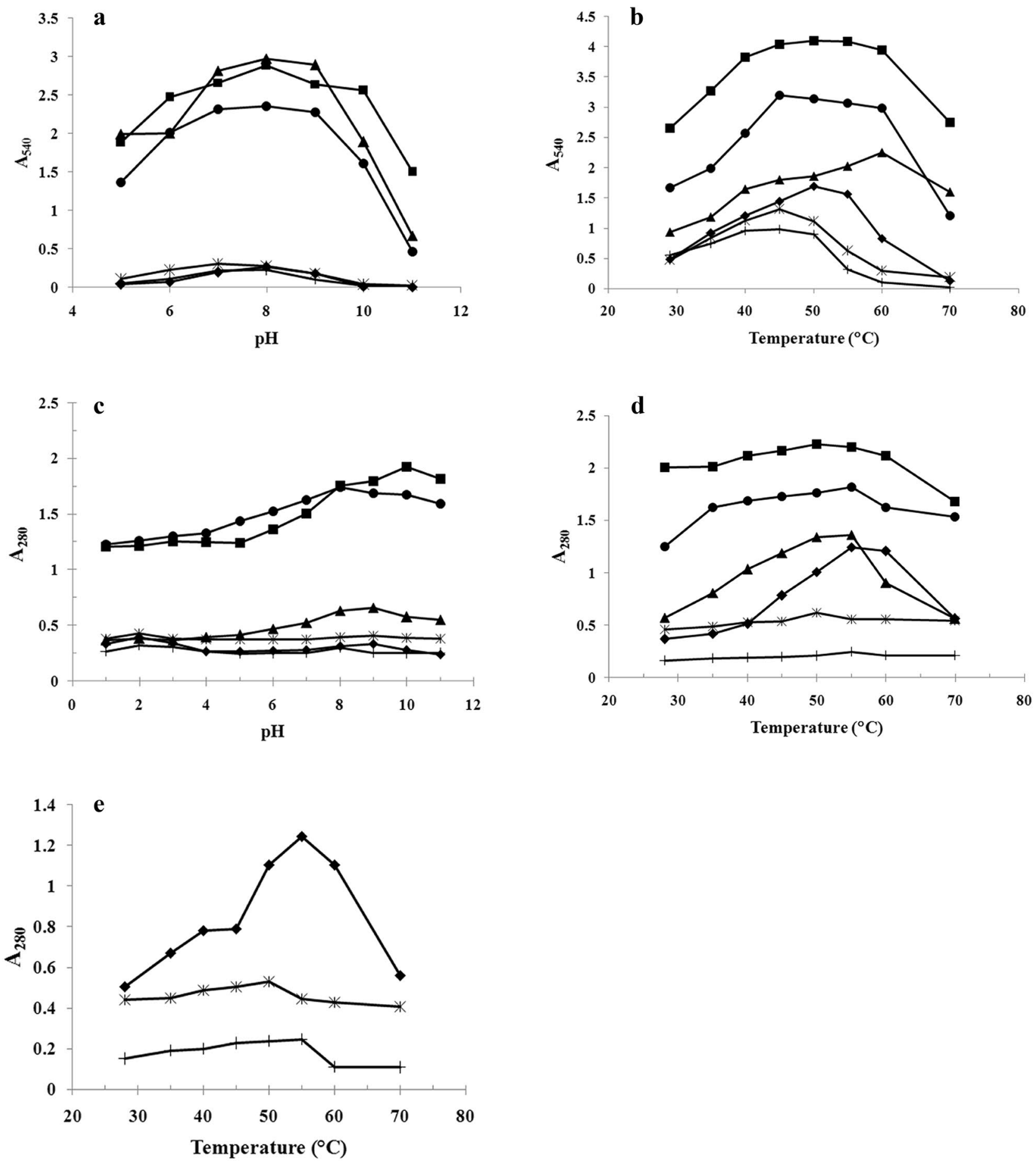

Figure 1. Optimum $\mathrm{pH}$ and optimum temperature for amylase (a, b), alkaline protease (c, d), and optimum temperature of pepsin-like enzyme (e) (-口-, Puntius gonionotus; -- -, Puntioplites proctozysron; - $\mathbf{\Delta}$-, Oreochromis niloticus; -•-, Hemibagrus spilopterus; -*-, Kryptopterus geminus, -+-; Ompok bimaculatus).

environmental conditions were compared among six fish species. In optimum conditions, Puntioplites proctozysron showed the highest activities of both amylase and protease, with specific activities of $7 \pm 1.2$ units $\mathrm{mg}^{-1}$ protein and $1634 \pm 115.5$ units $\mathrm{mg}^{-1}$ protein, respectively; the next highest activities were shown (in order) by the enzymes from Or. niloticus, Puntius gonionotus, and H. spilopterus. Low activities of both enzymes were observed in K. geminus and Om. bimaculatus [specific activities less than 1.5 units $\mathrm{mg}^{-1}$ protein (for amylase) and 595 units $\mathrm{mg}^{-1}$ protein (for alkaline protease)] (Fig. 2). Pepsin-like enzymes were apparent in the carnivo-

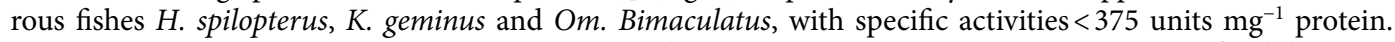
The digestive enzyme activities were also investigated at swamp temperature $\left(29^{\circ} \mathrm{C}\right)$, to evaluate food digestion capability. The enzyme activities were $42 \%-90 \%, 13 \%-69 \%$, and $24 \%-56 \%$ for amylase, alkaline protease, and 

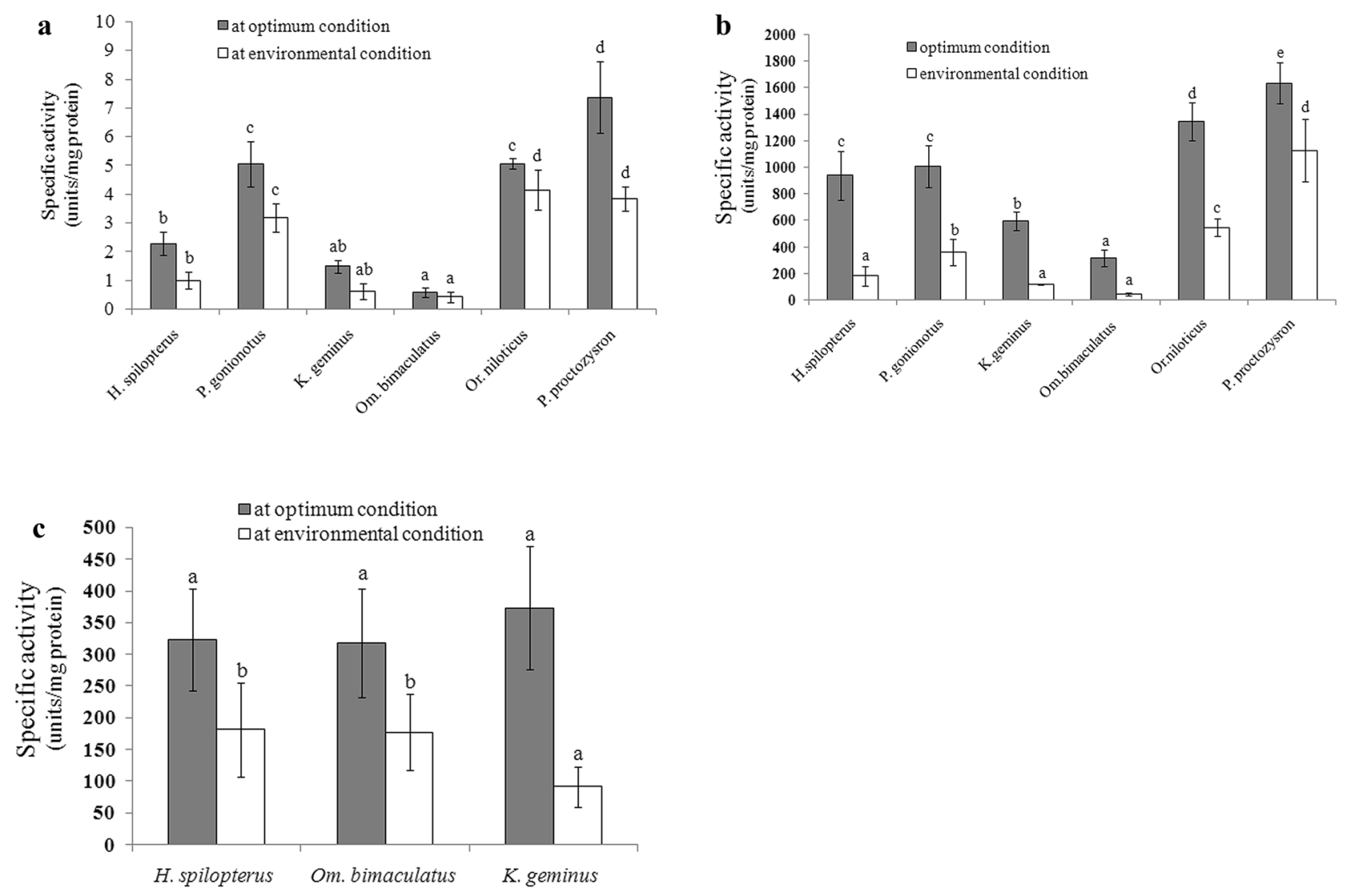

Figure 2. Activity comparisons of amylase (a), alkaline proteases (b), and pepsin-like enzyme (c) (Data are expressed as Mean \pm SD ( $n=3-8)$. The differences among means of the same condition (optimum condition or environmental condition) were compared by Duncan's multiple range tests. Different small letters indicate the significant differences at $P$ value $<0.05$.

pepsin-like enzyme, respectively, compared with those determined in optimum conditions, suggesting that the proteases, particularly alkaline protease, were more sensitive to temperature than amylase. Moreover, we found that the carnivorous fishes displayed lower amylase and alkaline protease activities than the omnivorous and herbivorous fishes in both temperature conditions.

Isoenzyme patterns and molecular weight. Amylases, alkaline proteases, and pepsin-like enzyme were separated by SDS-PAGE and the molecular weights of these enzymes were analyzed. Using $12 \%$ SDS gels revealed different patterns of the three enzymes in different fish species. In this zymographic analysis, clear bands on the dark background of the stained gel indicate the position of an enzyme that can hydrolyze substrate.

The six fish species contained one to three isoforms of amylase with estimated molecular weights from 35 to $>175 \mathrm{kDa}$ (Fig. 3a and Table 2). The number of isoforms of alkaline protease ranged from five to eight in the six fish species (Fig. 3b); the molecular weights were from 19.5 to $130 \mathrm{kDa}$, as indicated in Table 2. Zymographic results corresponded to enzyme activity analysis data; enzymes with high activity exhibited strong, clear bands, whereas enzymes with low activity showed weak bands on the gels. In the case of pepsin-like enzyme, no clear enzyme bands were observed with $100 \mu \mathrm{g}$ of total protein for samples from Om. bimaculatus or K. geminus although they exhibited specific activities of $318 \pm 85.9$ and $373 \pm 97.4$ units $\mathrm{mg}^{-1}$ protein, respectively (Fig. 2c). One clear band was detected for $H$. spilopterus pepsin-like enzyme, with molecular weight $24 \mathrm{kDa}$ (data not shown). The failure to detect pepsin zymographically might be because of the low amounts of sample used, and/ or because the enzyme did not refold properly when SDS was washed out of the gel.

Enzyme stability. The effects of incubation time, $\mathrm{pH}$, and temperature on enzyme activity were determined using crude enzymes samples to help understand more biochemical properties of the enzymes that will be useful for further study and application. Enzymes from three fish species (P. gonionotus, P. proctozysron, and Or. niloticus) exhibiting high activities of both amylase and alkaline protease in broad $\mathrm{pH}$ and temperature ranges were used for this experiment. Figure $4 \mathrm{a}$ shows the enzyme activities at different times of incubation in $0.2 \mathrm{M}$ Tris$\mathrm{HCl}$ buffer, $\mathrm{pH}$ 8.0. All three species exhibited the same pattern of enzyme stability. In the first 30 min of incubation, the activities of the alkaline proteases increased to $108 \%-125 \%$ and then maintained activities $>100 \%$ until $150 \mathrm{~min}$; while amylase activities decreased to $94 \%-84 \%$ before a slight increase to stabilize at $>92 \%$. Note that 

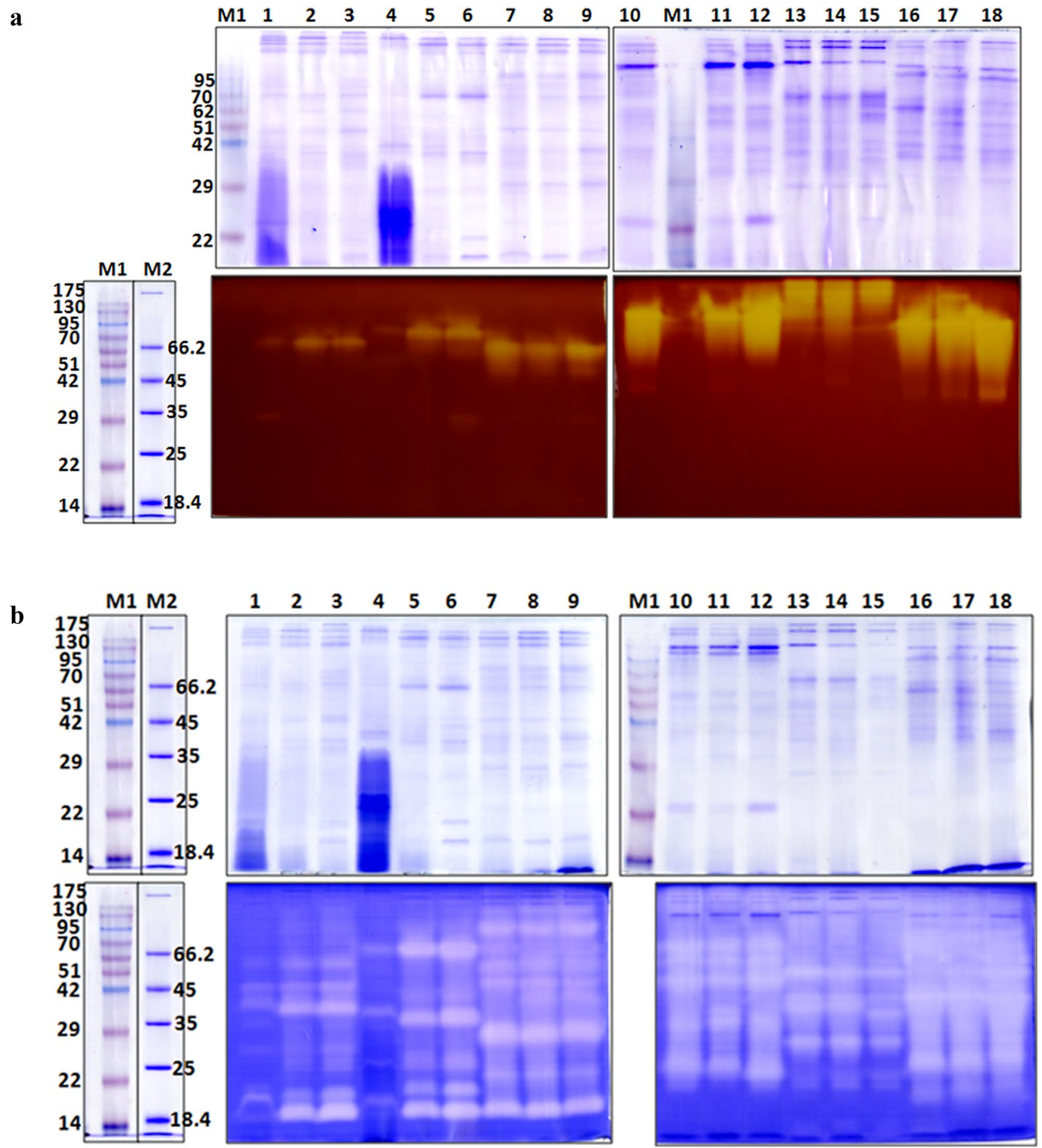

Figure 3. SDS gels stained with Coomassie brilliant blue R-250 and zymograms of amylase (a), alkaline proteases (b) (Lane M1; Pink plus prestained protein ladder (GeneDireX), lane M2; unstained protein molecular weight marker (Thermo Scientific), lanes 1-3; Ompok bimaculatus (n6, n7, n8), lanes 4-6; Kryptopterus geminus (n6, n7, n8), lanes 7-9; Hemibagrus spilopterus (n1, n2, n4), lanes 10-12; Puntius gonionotus (n5, n7, n8), lanes 13-15; Oreochromis niloticus (n5, n7, n8), lanes 16-18; Puntioplites proctozysron (n1, n2, n3)).

$100 \%$ relative activity was defined as the enzyme activity assayed at the same conditions, without a preincubation step; after preincubation, some of the enzymes showed higher activity.

Considering the effect of $\mathrm{pH}$, most of the enzymes from the tested fish species revealed high stability in a broad $\mathrm{pH}$ range (from 5.0 to 11.0 ) with enzyme activity up to $110 \%$ (Fig. $4 \mathrm{~b}$ ). However, in the case of P. gonionotus, the relative amylase activity decreased and remained at 55\% at $\mathrm{pH} 5.0$. At $\mathrm{pH} 2-5$, acid-induced denaturation of protein often occurs. Decreasing $\mathrm{pH}$ by adding acids (buffer $\mathrm{pH} 5.0$ in this case) to the enzyme solution (in extraction buffer, $\mathrm{pH} 7.5$ ) causes the side chain $-\mathrm{COO}^{-}$converted to $-\mathrm{COOH}$ resulting in changes in ionic 


\begin{tabular}{|l|l|l|l|l|l|l|}
\hline Fish species & \multicolumn{2}{|l|}{ Amylase } & \multicolumn{2}{l|}{ Alkaline proteases } & \multicolumn{2}{l|}{ Pepsin } \\
\hline & No & MW $(\mathbf{k D a})$ & No & MW $(\mathbf{k D a})$ & No & MW (kDa) \\
\hline Ompok bimaculatus & $1-2$ & 70,35 & 8 & $57,45,37,35,27,25,21,19.5$ & ND & ND \\
\hline Kryptopterus geminus & $1-2$ & $82.5,35$ & 6 & $66.5,41,35,26,21,19.5$ & ND & ND \\
\hline Hemibagrus spilopterus & $1-2$ & 66,35 & 8 & $130,95,56,45,40,29,23,19.5$ & 1 & 24 \\
\hline Puntius gonionotus & $1-2$ & 95,49 & 5 & $70,62,46.5,34,24$ & - & - \\
\hline Oreochromis niloticus & 3 & $>175,175,152$ & 6 & $51,38.5,37,27.5,23,21$ & - & - \\
\hline Puntioplites proctozysron & $2-3$ & $152,82,49$ & 7 & $80,67,62,51,35.5,25,20$ & - & - \\
\hline
\end{tabular}

Table 2. Number of isoenzyme and the estimated molecular weight of amylase, alkaline protease and pepsinlike enzyme. ND: not detectable.
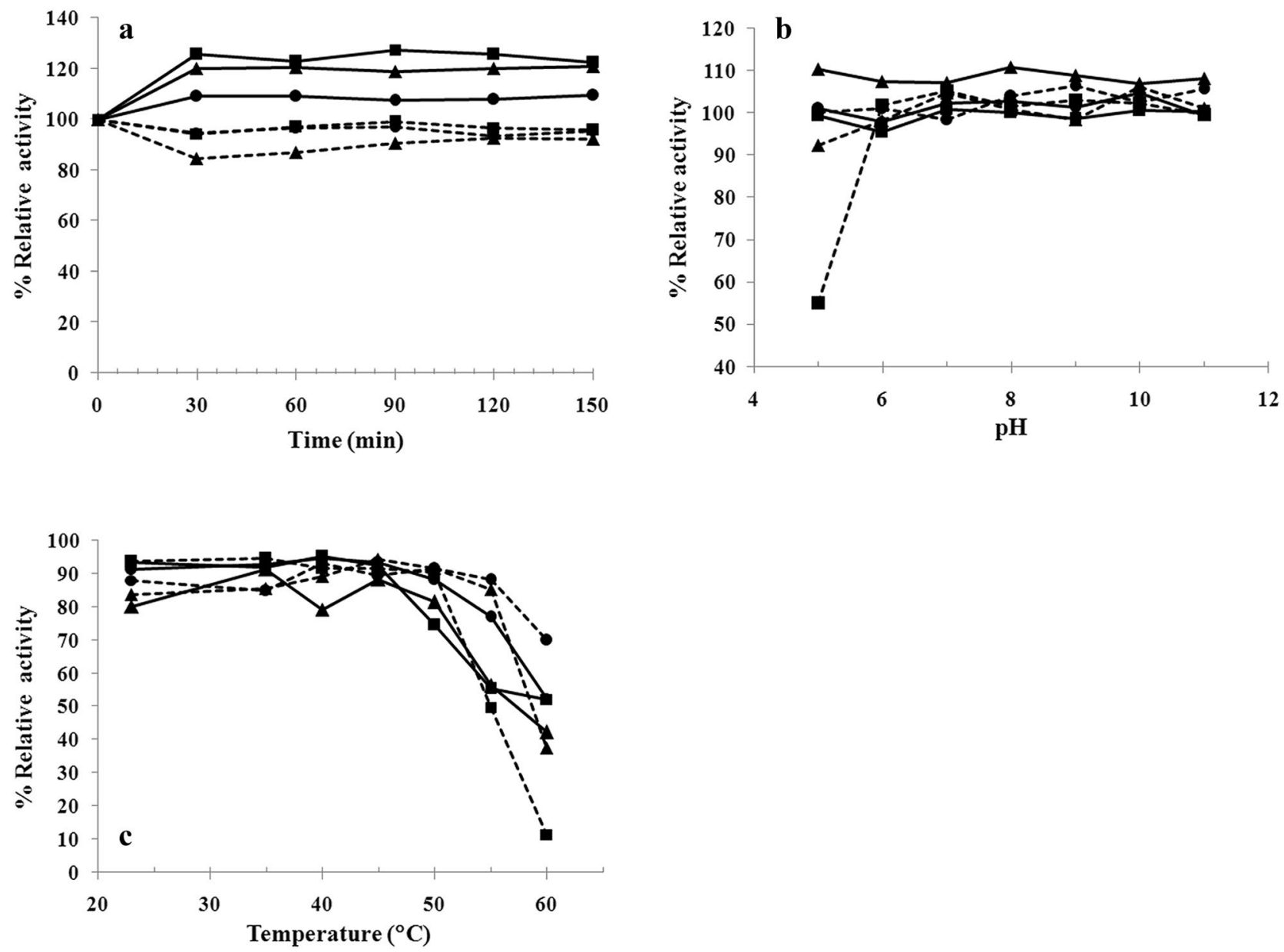

Figure 4. Effects of incubation time (a), $\mathrm{pH}(\mathbf{b})$ and temperature (c) on amylase and alkaline proteases activities (-口-, Puntius gonionotus; -- - Puntioplites proctozysron; - $\mathbf{\Delta}$-, Oreochromis niloticus. Dashed lines represent the relative activity of amylase, whereas solid lines represent the relative activity of alkaline proteases).

interaction between side chains, leading to unfolding and denaturation. The P. gonionotus amylase seems not able to refold after adding of an optimum buffer for activity assay. Figure $4 \mathrm{c}$ reveals the effect of temperature after incubation of enzyme for $1 \mathrm{~h}$ at $25-60^{\circ} \mathrm{C}$. Both the amylases and alkaline proteases from all three species exhibited high residual activities ( $>80 \%$ ) after incubation at 25 to $50^{\circ} \mathrm{C}$, but the activities dropped dramatically, to $11 \%-70 \%$, after incubation at higher temperature, most notably for P. gonionotus amylase.

\section{Discussion}

This research studied the biochemical properties of digestive enzymes from some freshwater fishes. The enzymes from the different fish species had various optimum $\mathrm{pHs}$ and temperatures for enzymatic activity. These data correlated with results from seven cyprinid fishes ${ }^{16}$ and Or. niloticus ${ }^{21}$. These results suggest that the enzymes may share conserved amino acid residues at the active site ${ }^{22,23}$. In other organisms such as bacteria (Bacillus cereus, 
Bacillus amyloliquefaciens BH072, and Aeribacillus pallidus C10), shrimp (Cherax albidus, Penaeus californiensis Holmes 1900, Penaeus vannamei Boone 1931, and Penaeus stylirostris Stimpson 1874), and other fish species (Osteochilus hasselti, Labiobarbus spilopleura, Osteochilus lini, Cyclocheilichthys repasson, Cyclocheilichthys apogon, Puntius brevis, Symphysodon aequifasciata, Polyodon spathula, Limia vittata, and Gambusia punctata), the amylases exhibit different optimum $\mathrm{pH}$ values, $6.0,7.0,8.0$, or $9.0^{10,21,24,25}$, whereas the proteinases or alkaline protease reveal wide ranges of optimum $\mathrm{pH}$ from 7.0 to $12.5^{13,19,21,24,26-28}$. In the present study, different optimum $\mathrm{pH}$ values were observed for alkaline protease, with the values varying from 8.0 to 10.0 depending on the fish species. Moreover, acidic proteases were also observed. Low activity of this pepsin-like enzyme was observed in H. spilopterus, Om. bimaculatus, and K. geminus. However, the maximum activity of the enzyme was detected at $\mathrm{pH} 2.0$.

Fish are cold-blooded; thus, the water temperature influences their body temperature, growth rate, and food consumption ${ }^{29-31}$. The growth rate is associated with digestive capability, which is derived from digestive enzyme activity. Study of the digestive enzyme activity at different temperatures will help with sustainable development of aquaculture. In this study, we found that all six species of freshwater fish showed low digestive enzyme activity at environmental temperature $\left(29^{\circ} \mathrm{C}\right)$, particularly for alkaline proteases whose activities dropped to $13 \%-69 \%$ of those in the optimum conditions. In addition, the carnivorous fishes displayed lower amylase and alkaline protease activities than the omnivorous and herbivorous fishes.

Isoenzyme analysis and molecular weight determination of amylase and protease enzymes have been performed in bacteria, shrimp, and some species of fishes. Noticeably, bacterial enzymes display only one isoform with molecular weight ranging from 28 to $68 \mathrm{kDa}$, whereas fish and shrimp contain many isoforms ${ }^{10,12,13,16,19,21,24-28}$. The several isoforms of digestive enzymes seen in digestive tracts of fish may derive from the floral bacteria ${ }^{32}$. However, more experiments have to further investigate bacterial enzymes such as the expression level, biochemical properties, and molecular weights compared to enzyme extracts from digestive tracts of fish.

In the present study, the number of isoenzymes of proteolytic and amylolytic enzymes ranged from one to eight and two to eight with molecular weights between 12 and $160 \mathrm{kDa}$ and 26 and $175 \mathrm{kDa}$, respectively. In the case of pepsin-like enzymes, although three fish species in this study exhibited specific activities around 320-375 units $\mathrm{mg}^{-1}$ protein, only one such enzyme (that from H. spilopterus) could be detected on a zymographic gel, and the band was very faint.

$\mathrm{pH}$ and temperature stabilities have been reported for bacterial $\alpha$-amylases - $^{10,11,33,34}$ and bacterial proteases ${ }^{33,35}$. Amylases from Bacillus showed high stability at pHs between 5.0 and 10.0, and temperatures between 20 and $100{ }^{\circ} \mathrm{C}$ with residual activity $>70 \%$; proteases had residual activity $>70 \%$ at pH 8.0 to 12.0 and 30 to $60{ }^{\circ} \mathrm{C}$. For marine fish, the digestive enzymes from Atlantic salmon (Salmo salar) ${ }^{36}$ and thornback ray (Raja clavata) ${ }^{37}$ have been reported. For Atlantic salmon, trypsin showed high stability with $>92 \%$ residual activity after incubation at $37^{\circ} \mathrm{C}$ for $24 \mathrm{~h}$, and alkaline protease from thornback ray was highly stable at $\mathrm{pH} 5.0$ to 11.0 and $4{ }^{\circ} \mathrm{C}$. However, little information has been reported on stability of digestive enzymes from freshwater fish. Seven species of fishes including of $P$. gonionotus have been reported the biochemical properties of digestive enzyme ${ }^{16}$. However, molecular weight and enzyme stabilities have not been determined. Chaijareon and Thongruang (2016) determined the stability of amylase and protease from Or. niloticus. They found that the protease exhibited $50 \%$ residual activity after $360 \mathrm{~min}$ of incubation at $60^{\circ} \mathrm{C}$ at $\mathrm{pH} 8.0$, while the amylase activity increased fivefold in the first $30 \mathrm{~min}$ and declined three-fold of its initial activity after $90 \mathrm{~min}$. In contrast, our experiments showed that both amylase and alkaline protease from Or. niloticus and also those from P. proctozysron and P. gonionotus exhibited high stability at a wide range of $\mathrm{pH}(6.0-12.0)$ and temperature $\left(25-50^{\circ} \mathrm{C}\right)$, retaining more than $95 \%$ and $75 \%$ of their initial activities, respectively. Moreover, the enzymes were stable on incubation in buffer $\mathrm{pH}$ 8.0 at room temperature $\left(23^{\circ} \mathrm{C}\right)$ for $150 \mathrm{~min}$. High stability of amylase and alkaline protease, digestive enzymes from freshwater fishes, was found in this study and is good evidence for further study and application.

\section{Materials and methods}

Materials. Casein (sodium salt, from bovine milk, cat.no. C-8654) and starch (from rice, cat.no. S-7260) were purchased from Sigma-Aldrich, USA. Quick Start $1 \times$ Bradford dye reagent (cat.no. 5000205) was from Bio-Rad, Bio-Rad laboratories, Hercules, California. Acrylamide (cat.no. 17-1302-02) and N, N'-methylenebisacrylamide (cat.no. 17-1304-02) were purchased from Amersham Biosciences, USA. Sodium dodecylsulfate (cat.no. DB0485), soluble starch (cat.no.SB0904) and $\beta$-mercaptoethanol (cat.no. MB0338) were from Bio Basic Canada Inc. 3,5-Dinitrosalicylic acid was purchased from Fluka, USA. Chemical reagents for preparation of buffers were purchased from Carlo Erba (France), Scharlau (Barcelona, Spain), and Ajax Finechem (MA, USA).

Sample collection and preparation. Samples were collected as part of a fish faunal survey in Lam Nam Choen swamp, Nongruea district, Khon Kaen province, Thailand, by using nets. Fish were killed in ice without using any chemical agent. The condition did not severely distress or cause lasting harm to sentient fish. The body weight and body length were recorded. Whole digestive tracts were dissected and weighed before calculation of DSI [(digestive tract weight/body weight $) \times 100]$. The digestive tracts were subsequently rinsed with distilled water and then homogenized on ice by uses of pestle and mortar with a buffer $(0.05 \mathrm{M}$ Tris- $\mathrm{HCl}, \mathrm{pH} 7.5)$ using $1 \mathrm{~g}$ of digestive tract per $3 \mathrm{ml}$ of buffer. The homogenized samples were centrifuged by uses of Rotina 380R centrifuge (Hettich) at $22,000 \times g$ at $4^{\circ} \mathrm{C}$ for $30 \mathrm{~min}$. Supernatants containing digestive enzymes were subjected to further study or kept at $-20^{\circ} \mathrm{C}$ until use. Determination of protein content was performed by using Bradford reagent ${ }^{38}$. Bovine serum albumin was used for the calibration curve of protein concentration. 
All methods were carried out in accordance with relevant guidelines and regulations. All experimental protocols and the care and use of experimental animals complied with animal welfare laws of Thailand, and guidelines and policies approved by ThaiIACUC (permit reference number U1-04,584-2559).

Time course assay. To determine the initial velocity of enzymatic reaction, the enzyme activity was observed after incubation of enzyme with substrate for 5 to $30 \mathrm{~min}$. One reaction for one time point of amylase assay contained $20 \mu \mathrm{l}$ of supernatant containing digestive enzymes or crude enzyme extract, $500 \mu \mathrm{l}$ of $0.5 \%$ starch solution (solubilized in $0.05 \mathrm{M}$ Tris- $\mathrm{HCl}, \mathrm{pH} 8.0$ ), and $480 \mu \mathrm{l}$ of $0.2 \mathrm{M}$ Tris- $\mathrm{HCl}, \mathrm{pH}$ 8.0. For protease assay, one reaction contained $25 \mu \mathrm{l}$ of crude enzyme extract, $250 \mu \mathrm{l}$ of $1 \%$ casein (solubilized in $0.05 \mathrm{M}$ Tris- $\mathrm{HCl}, \mathrm{pH} 7.5$ ), and $725 \mu \mathrm{l}$ of $0.2 \mathrm{M}$ Tris- $\mathrm{HCl}, \mathrm{pH}$ 8.0. The reactions were incubated at room temperature $\left(23^{\circ} \mathrm{C}\right)$ for $5,10,15,20$, 25 , or $30 \mathrm{~min}$. Five hundred microliters of $3^{\prime}, 5^{\prime}$-dinitrosalicylic acid (DNS) solution and $12 \%$ trichloroacetic acid were added to terminate amylase and protease reactions, respectively. The reaction mixtures were subsequently centrifuged at $16,000 \times g$ for $10 \mathrm{~min}$ to sediment remaining substrate and denatured enzyme. Supernatants containing the catalytic products of amylase and protease were taken to measure absorbance at 540 and $280 \mathrm{~nm}$, respectively. The absorbance values were plotted against the incubation time.

Determination of optimum $\mathrm{pH}$ of enzyme reaction. The activities of amylase and protease were observed at $\mathrm{pH} 5-11$ and $\mathrm{pH} \mathrm{1-11}$, respectively. Buffers used $(0.2 \mathrm{M})$ comprised $\mathrm{KCl}-\mathrm{HCl}(\mathrm{pH} \mathrm{1.0)}$, glycine$\mathrm{HCl}(\mathrm{pH} 2.0$ and 3.0), sodium acetate ( $\mathrm{pH} 4.0$ and 5.0), sodium phosphate ( $\mathrm{pH} 6.0$ and 7.0), Tris- $\mathrm{HCl}(\mathrm{pH} 8.0$ and 9.0), and glycine- $\mathrm{NaOH}(\mathrm{pH} 10.0$ and 11.0). One milliliter of reaction for amylase assay contained $20 \mu \mathrm{l}$ of crude enzyme extract, $500 \mu \mathrm{l}$ of $0.5 \%$ starch solution (solubilized in $0.05 \mathrm{M}$ Tris- $\mathrm{HCl}, \mathrm{pH} 8.0$ ), and $480 \mu \mathrm{l}$ of $0.2 \mathrm{M}$ buffer. After incubation at room temperature $\left(23^{\circ} \mathrm{C}\right)$ for $7 \mathrm{~min}$, the reactions were stopped with $500 \mu \mathrm{l}$ of DNS solution, boiled for $10 \mathrm{~min}$, and centrifuged at $16,000 \times \mathrm{g}$ for $10 \mathrm{~min}$. Absorbance of the supernatants was measured at $540 \mathrm{~nm}$.

For protease assay, one reaction included $25 \mu \mathrm{l}$ of crude enzyme extract, $250 \mu \mathrm{l}$ of $1 \%$ casein (solubilized in $0.05 \mathrm{M}$ Tris-HCl, pH 7.5), and $725 \mu \mathrm{l}$ of $0.2 \mathrm{M}$ buffer as described above. The reaction was allowed to proceed at room temperature $\left(23^{\circ} \mathrm{C}\right)$ for $7 \mathrm{~min}$ and was then terminated with $12 \%$ trichloroacetic acid. The reactions were incubated on ice for $30 \mathrm{~min}$ then centrifuged to separate denatured casein and enzyme. Absorbance of the resulting supernatants was measured at $280 \mathrm{~nm}$.

Determination of optimum temperature of enzyme reaction. Amylase and protease reactions were monitored at $29,35,40,45,50,55,60$, and $70^{\circ} \mathrm{C}$. One milliliter of reaction for amylase assay contained $20 \mu \mathrm{l}$ of crude enzyme extract, $500 \mu \mathrm{l}$ of $0.5 \%$ starch solution (solubilized in $0.05 \mathrm{M}$ Tris-HCl, pH 8.0), and $480 \mu \mathrm{l}$ of $0.2 \mathrm{M}$ of the optimum buffer (as determined in section "Determination of optimum enzyme reaction $\mathrm{pH}$ "). In assay of protease activity, the reaction contained $25 \mu \mathrm{l}$ of crude enzyme extract, $250 \mu \mathrm{l}$ of $1 \%$ casein (solubilized in $0.05 \mathrm{M}$ Tris- $\mathrm{HCl}, \mathrm{pH} 7.5$ ), and $725 \mu \mathrm{l}$ of optimum buffer. The reactions were incubated for 7 min at various temperatures (listed above). The reactions were terminated, incubated on ice for $30 \mathrm{~min}$, and centrifuged at 16, $000 \times g$ for $10 \mathrm{~min}$. The supernatants were measured at 540 and $280 \mathrm{~nm}$ to determine the catalytic products of amylase and protease, respectively.

Determination and comparison of amylase and protease activities in optimum and environmental conditions. Five to eight specimens of each fish species were determined for both amylase and protease activities. One milliliter of amylase reaction contained $20 \mu \mathrm{l}$ of crude enzyme extract, $500 \mu \mathrm{l}$ of $0.5 \%$ starch solution, and $480 \mu \mathrm{l}$ of $0.2 \mathrm{M}$ optimum buffer. The protease-assay reaction contained $25 \mu \mathrm{l}$ of crude enzyme extract, $250 \mu \mathrm{l}$ of $1 \%$ casein, and $725 \mu \mathrm{l}$ of optimum buffer. The reactions were incubated for $10 \mathrm{~min}$ at the optimum temperature for each enzyme. DNS solution and $12 \%$ trichloroacetic acid were used to terminate the amylase and protease reactions, respectively. Reactions were incubated on ice for $30 \mathrm{~min}$ (for protease assay) or boiled for $10 \mathrm{~min}$ (for amylase assay) then centrifuged at $16,000 \times g$ for $10 \mathrm{~min}$ to sediment remaining substrate and denatured enzyme. The resulting supernatants were taken to measure the absorbance at 540 and $280 \mathrm{~nm}$, respectively. The contents of product released from substrate were calculated from tyrosine and maltose standard curves, respectively. The enzyme activity and specific activity were subsequently analyzed and compared between fish species. One unit of protease activity was defined as the amount of enzyme required to generate one nmol of tyrosine equivalents in $1 \mathrm{~min}$; one unit of amylase activity was defined as the amount of enzyme required to produce one mmol of maltose in $1 \mathrm{~min}$. Specific activity is the enzyme activity (nmol tyrosine equivalents $\mathrm{min}^{-1}$ for proteases or $\mathrm{mmol} \mathrm{maltose} \mathrm{min}^{-1}$ for amylase) per $\mathrm{mg}$ of total protein and therefore it was reported as units $\mathrm{mg}^{-1}$ protein.

The activities of both digestive enzymes were also determined at swamp temperature; the reaction components and procedure were similar to reactions in optimum conditions, but the assay temperature was changed to $29^{\circ} \mathrm{C}$ for all samples.

Control reactions were also conducted for all samples. The reactions contained all components as described for the catalytic reaction, but the DNS solution or $12 \%$ trichloroacetic acid were pipetted into the reaction before adding crude enzyme. The obtained absorbance values were subtracted from those for catalytic reactions.

Statistical analysis. Enzyme activities are expressed as mean \pm SD. Data were analyzed by one-way analysis of variance (IBM SPSS statistics software v.19). Post-hoc multiple comparisons were performed using Duncan's test. Differences were considered significant at $P<0.05$. 
Determination of isoenzyme pattern and molecular weight analysis. Total crude enzymes (25 and $100 \mu \mathrm{g}$ respectively) were used to analyze amylase and protease isoenzymes, by using sodium dodecyl sulfate (SDS)-polyacrylamide gel electrophoresis and zymography. Crude enzyme samples were mixed with SDS sample buffer without any reducing agent $(62.5 \mathrm{mM}$ Tris- $\mathrm{HCl}, \mathrm{pH} 6.8,25 \%$ glycerol, $2 \% \mathrm{SDS}, 0.05 \%$ bromophenol blue) and loaded on a $5 \%$ stacking gel. The proteins were separated using a $12 \%$ separating gel. Electrophoresis was performed at $180 \mathrm{~V}$ and $4{ }^{\circ} \mathrm{C}$ using Mini-PROTEAN Tetra Cell apparatus (Bio-Rad).

After electrophoresis, two gels with a similar pattern of sample loading were separately examined. The first gel was stained with Coomassie Brilliant Blue [0.15\% (w/v) Coomassie Brilliant Blue R-250, 50\% ethanol, 10\% glacial acetic acid] to observe the protein pattern. Staining was performed for $1-2 \mathrm{~h}$ and then destaining $(30 \%$ ethanol, $10 \%$ glacial acetic acid) was carried out until the background was clear. The protein bands were dark blue. For in-gel analysis of amylase activity, the second gel was soaked for $20 \mathrm{~min}$ in $0.05 \mathrm{M}$ Tris- $\mathrm{HCl}, \mathrm{pH}$ 8.0, containing $2 \%$ Triton X-100 to remove SDS and washed for 5 min with the same buffer without Triton X-100. The gel was immersed in $2 \%$ soluble starch (solubilized in $0.05 \mathrm{M}$ Tris- $\mathrm{HCl}, \mathrm{pH} 8.0$ ) and incubated at $4{ }^{\circ} \mathrm{C}$ for $30 \mathrm{~min}$ before moving to $45^{\circ} \mathrm{C}$. The enzyme was allowed to react in-gel for $1 \mathrm{~h}$. The starch solution was discarded and the gel was rinsed with water. Iodine solution was used to stain the gel. The presence of starch produced a brownish-purple color on the gel. A clear band thus showed the position of amylase (i.e., degradation of the starch); such bands were used to determine enzyme molecular weight by comparison of retention factors with those of proteins of standard molecular weight on the Coomassie Brilliant Blue-stained gel.

Protein markers with different molecular weights were used in this study. M1 was Pink Plus-prestained protein ladder from GeneDirex and contained 11 proteins in the range $10-175 \mathrm{kDa}$. The manufacturer does not provide any detail about the specific proteins in this marker mixture. M2 was unstained protein molecular weight marker from Thermo Scientific, containing chicken egg white lysozyme ( $14.4 \mathrm{kDa})$, bovine milk $\beta$-lactoglobulin $(18.4 \mathrm{kDa})$, Escherichia coli REase Bsp98I (25 kDa), porcine muscle lactate dehydrogenase (35 kDa), chicken egg white ovalbumin $(45 \mathrm{kDa})$, bovine plasma bovine serum albumin $(66.2 \mathrm{kDa})$, and $E$. coli $\beta$-galactosidase $(116.0 \mathrm{kDa})$.

To detect protease activity in-gel, the procedure was similar to that described above for amylase. SDS was removed by using $0.05 \mathrm{M}$ Tris- $\mathrm{HCl}$ buffer, $\mathrm{pH} 8.0$, containing $2 \%$ Triton X-100. Gels were rinsed with the same buffer without Triton X-100 before soaking in $2 \%$ casein (solubilized in $0.05 \mathrm{M}$ Tris- $\mathrm{HCl}, \mathrm{pH} 8.0$ ) at $4{ }^{\circ} \mathrm{C}$ for $30 \mathrm{~min}$. Gels were then incubated with gentle shaking at $45^{\circ} \mathrm{C}$ for $1 \mathrm{~h}$. Casein solution was removed and the gels were rinsed with water before staining with Coomassie Brilliant Blue R-250. Protein staining was performed at room temperature for 1 to $2 \mathrm{~h}$. Destaining was carried out for $30 \mathrm{~min}$ or until a clear band was visualized against the dark blue background. The molecular weight of proteases was analyzed as described above for amylases.

Effects of incubation time, $\mathrm{pH}$, and temperature on enzyme activity. Enzyme activity was determined after incubation of crude enzyme in $0.2 \mathrm{M}$ Tris- $\mathrm{HCl}, \mathrm{pH} 8.0$, for 30, 60, 90, 120, or $150 \mathrm{~min}$. At each time point, enzyme mixture was aliquoted and substrate solution was added $(0.5 \%$ starch for amylase assay, or $1 \%$ casein for protease assay). The reaction was incubated at room temperature $\left(2{ }^{\circ} \mathrm{C}\right)$. The enzymatic product was detected by measuring the absorbance as described above. The enzyme activity and relative activity were calculated; $100 \%$ relative activity was defined as the enzyme activity measured in the same conditions, without a pre-incubation step.

The effect of $\mathrm{pH}$ on enzyme activity was investigated. Crude enzyme was incubated for $1 \mathrm{~h}$ at room temperature $\left(23^{\circ} \mathrm{C}\right)$ in buffer at $\mathrm{pH} 5-11$. Enzyme solution was aliquoted and mixed with the optimum buffer and substrate for activity testing. The residual activity of enzyme was monitored and is reported as \% relative activity. The activities at the optimum $\mathrm{pH}$ without pre-incubation were used as control ( $100 \%$ of relative activity).

To determine the effect of temperature, crude enzyme mixed with $0.2 \mathrm{M}$ Tris- $\mathrm{HCl}, \mathrm{pH} 8.0$, was incubated at $23-60{ }^{\circ} \mathrm{C}$ for $1 \mathrm{~h}$. Substrate and the optimum buffer for reaction were mixed with the enzyme solution before assay at the optimum reaction temperature. The $100 \%$ of relative activity at optimum temperature, without preincubation step, was used as control.

Received: 5 February 2020; Accepted: 28 February 2021

Published online: 11 March 2021

\section{References}

1. Tokes, Z. A., Woon, W. C. \& Chambers, S. M. Digestive enzymes secreted by the carnivorous plant Nepenthes macferlanei L.. Planta (Ber.) 119, 39-46 (1974).

2. Amagase, S., Mori, M. \& Nakayama, S. Enzymatic digestion of insects by Nepenthes secretion and Drosera peltata extract: proteolytic and chitinolytic activities. J. Biochem. 72, 765-767. https://doi.org/10.1093/oxfordjournals.jbchem.a129956 (1972).

3. Gopinath, S. C. B. et al. Biotechnological processes in microbial amylase production. BioMed. Res. Int. https://doi. org/10.1155/2017/1272193 (2017).

4. Kirk, O., Borchert, T. V. \& Fuglsang, C. C. Industrial enzyme applications. Curr. Opin. Biotechnol. 13, 345-351. https://doi. org/10.1016/S0958-1669(02)00328-2 (2002).

5. Singh, K., Ahmad, F., Singh, V. K., Kayastha, K. \& Kayastha, A. M. Purification, biochemical characterization and Insilico modeling of a-amylase from Vicia faba. J. Mol. Liq. 234, 133-141. https://doi.org/10.1016/j.molliq.2017.03.058 (2017).

6. Ghalati, R. E., Shamili, M. \& Homaei, A. Guava (Psidium guajava L.) leaf protease activity enriched by controlled stress and putrescine application. Sci. Hortic. 248, 105-111. https://doi.org/10.1016/j.scienta.2019.01.010 (2019).

7. Sun, Q., Zhang, B., Yan, Q. J. \& Jiang, Z. Q. Comparative analysis on the distribution of protease activities among fruits and vegetable resources. Food Chem. 213, 708-713. https://doi.org/10.1016/j.foodchem.2016.07.029 (2016).

8. Zeng, F. \& Cohen, A. C. Comparison of $\alpha$-amylase and protease activities of a zoophytophagous and two phytozoophagous Heteroptera. Comp. Biochem. Physiol. A. 126, 101-106. https://doi.org/10.1016/S1095-6433(00)00193-8 (2000). 
9. Darvishzadeh, A., Hosseininaveh, V. \& Ghamari, M. Identification and biochemical characterisation of $\alpha$-amylase in the alimentary tract of Mediterranean fruit fly, Ceratitis capitata (Wiedemann) (Diptera: Tephritidae). Arch. Phytopathol. Plant Protect. 46, 1061-1069. https://doi.org/10.1080/03235408.2012.757858 (2012).

10. Du, R. et al. Purification and characterization of novel thermostable and Ca-independent $\alpha$-amylase produced by Bacillus amyloliquefaciens BH072. Int. J. Biol. Macromol. 115, 1151-1156. https://doi.org/10.1016/j.ijbiomac.2018.05.004 (2018).

11. Wu, X., Wang, Y., Tong, B., Chen, X. \& Chen, J. Purification and biochemical characterization of a thermostable and acidstable alpha-amylase from Bacillus licheniformis B4-423. Int. J. Biol. Macromol. 109, 329-337. https://doi.org/10.1016/j.ijbio mac.2017.12.004 (2018).

12. Falcon-Hidalgo, B., Forrellat-Barrios, A., Farnes, O. C. \& Hernandez, K. U. Digestive enzymes of two freshwater fishes (Limia vittata and Gambusia punctata) with different dietary preferences at three developmental stages. Comp. Biochem. Physiol. B 158, 136-141. https://doi.org/10.1016/j.cbpb.2010.10.009 (2011).

13. Ji, H., Sun, H. T. \& Xiong, D. M. Studies on activity, distribution, and zymogram of protease, $\alpha$-amylase, and lipase in the paddlefish Polyodon spathula. Fish Physiol. Biochem. 38, 603-613. https://doi.org/10.1007/s10695-011-9541-9 (2012).

14. Gomez, A. V. A., Gomez, G., Chamorro, E., Bustillo, S. \& Leiva, L. C. Digestive aspartic proteases from sábalo (Prochilodus lineatus): Characterization and application for collagen extraction. Food Chem. 269, 610-617. https://doi.org/10.1016/j.foodc hem.2018.07.043 (2018).

15. Nasri, R. et al. Calcium dependent, alkaline detergent-stable trypsin from the viscera of Goby (Zosterisessor ophiocephalus): Purification and characterization. Process Biochem. 47, 1957-1964. https://doi.org/10.1016/j.procbio.2012.07.002 (2012).

16. Champasri, C. \& Champasri, T. Biochemical characterization, activity comparison and isoenzyme analysis of amylase and alkaline proteases in seven cyprinid fishes. J. Fish Aquat. Sci. 12, 264-272. https://doi.org/10.3923/jfas.2017.264.272 (2017).

17. Al-Tameemi, R., Aldubaikul, A. \& Salman, N. A. Comparative study of a-amylase activity in three cyprinid species of different feeding habits from Southern Iraq. Turk. J. Fish Aquat. Sc. 10, 411-414. https://doi.org/10.4194/trjfas.2010.0315 (2010).

18. Hidalgo, M. C., Urea, E. \& Sanz, A. Comparative study of digestive enzymes in fish with different nutritional habits Proteolytic and amylase activities. Aquaculture 170, 267-283. https://doi.org/10.1016/S0044-8486(98)00413-X (1999).

19. NavarretedelToro, M. A., Garcia-Carreno, F. L. \& Cordova-Murueta, J. H. Comparison of digestive proteinases in three penaeids. Aquaculture 317, 99-106. https://doi.org/10.1016/j.aquaculture.2011.03.035 (2011).

20. Nelson, J. S., Grande, T. C. \& Wilson, M. V. H. Fishes of the World (John Wiley \& Sons, 2016).

21. Chaijaroen, T. \& Thongruang, C. Extraction, characterization and activity of digestive enzyme from Nile tilapia (Oreochromis niloticus) viscera waste. Int. Food Res. J. 23, 1432-1438 (2016).

22. Lu, Y., Zen, K. C., Muthukrishnan, S. \& Kramer, K. J. Site-directed mutagenesis and functional analysis of active site acidic amino acid residues D142, D144 and E146 in Manduca sexta (tobacco hornworm) chitinase. Insect Biochem. Mol. Biol. 32, 1369-1382. https://doi.org/10.1016/S0965-1748(02)00057-7 (2002).

23. Talley, K. \& Alexov, E. On the pH-optimum of activity and stability of proteins. Proteins 78, 2699-2706. https://doi.org/10.1002/ prot.22786 (2010).

24. Chong, A. S. C., Hashim, R., Chow-Yang, L. \& Ali, A. B. Partial characterization and activities of proteases from the digestive tract of discus fish (Symphysodon aequifasciata). Aquaculture 203, 321-333. https://doi.org/10.1016/S0044-8486(01)00630-5 (2002).

25. Moreau, Y., Desseaux, V., Koukiekolo, R., Marchis-Mouren, G. \& Santimone, M. Starch digestion in tropical fishes: isolation, structural studies and inhibition kinetics of a-amylases from two tilapias Oreochromis niloticus and Sarotherodon melanotheron. Comp. Biochem. Physiol. B. 128, 543-552. https://doi.org/10.1016/S1096-4959(00)00358-4 (2001).

26. Fernandez, I., Moyano, F. J., Diaz, M. \& Martinez, T. Characterization of $a$-amylase activity in five species of Mediterranean sparid fishes (Sparidae, Teleostei). J. Exp. Mar. Biol. Ecol. 262, 1-12. https://doi.org/10.1016/S0022-0981(01)00228-3 (2001).

27. Coccia, E., Varricchio, E. \& Paolucci, M. Digestive enzymes in the crayfish Cherax albidus: Polymorphism and partial characterization. Int. J. Zool. https://doi.org/10.1155/2011/310371 (2011).

28. Yildirim, V. et al. Purification and biochemical characterization of a novel thermostable serine alkaline protease from Aeribacillus pallidus C10: a potential additive for detergents. J. Enzyme Inhib. Med. Chem. 32, 468-477. https://doi.org/10.1080/14756 366.2016.1261131 (2017).

29. Kausar, R. \& Salim, M. Effect of water temperature on the growth performance and feed conversion ratio of Labeo rohita. Pak. Vet. J. 26, 105-108 (2006).

30. Britz, P. J., Hecht, T. \& Mangold, S. Effect of temperature on growth, feed consumption and nutritional indices of Haliotis midae fed a formulated diet. Aquaculture 152, 191-203. https://doi.org/10.1016/S0044-8486(97)00002-1 (1997).

31. Azevedo, P. A., Cho, C. Y., Leeson, S. \& Bureau, D. P. Effects of feeding level and water temperature on growth, nutrient and energy utilization and waste outputs of rainbow trout (Oncorhynchus mykiss). Aquat. Living Resour. 11, 227-238. https://doi.org/10.1016/ S0990-7440(98)89005-0 (1998).

32. Bairagi, A., Ghosh, K. S., Sen, S. K. \& Ray, A. K. Enzyme producing bacterial flora isolated from fish digestive tracts. Aquac. Int. 10, 109-121. https://doi.org/10.1023/A:1021355406412 (2002).

33. Hmidet, N. et al. Alkaline proteases and thermostable $\alpha$-amylase co-produced by Bacillus licheniformis $\mathrm{NH} 1$ : characterization and potential application as detergent additive. Biochem. Eng. J. 47, 71-79. https://doi.org/10.1016/j.bej.2009.07.005 (2009).

34. Vaikundamoorthy, R., Rajendran, R., Selvaraju, A., Moorthy, K. \& Perumal, S. Development of thermostable amylase enzyme from Bacillus cereus for potential antibiofilm activity. Bioorg. Chem. 77, 494-506. https://doi.org/10.1016/j.bioorg.2018.02.014 (2018).

35. Sellami-Kamoun, A. et al. Stability of thermostable alkaline protease from Bacillus licheniformis RP1 in commercial solid laundry detergent formulations. Microbiol. Res. 163, 299-306. https://doi.org/10.1016/j.micres.2006.06.001 (2008).

36. Krogdahl, A., Sundby, A. \& Holm, H. Characteristics of digestive processes in Atlantic salmon (Salmo salar). Enzyme pH optima, chyme pH, and enzyme activities. Aquaculture 449, 27-36. https://doi.org/10.1016/j.aquaculture.2015.02.032 (2015).

37. Lassoued, I. et al. Digestive alkaline proteases from thornback ray (Raja clavata): characteristics and applications. Int. J. Biol. Macromol. 80, 668-675. https://doi.org/10.1016/j.ijbiomac.2015.07.038 (2015).

38. Bradford, M. M. A rapid and sensitive method for the quantitation of microgram quantities of protein utilizing the principle of protein-dye binding. Anal. Biochem. 72, 248-254. https://doi.org/10.1016/0003-2697(76)90527-3 (1976).

\section{Acknowledgements}

We would like to thank Khon Kaen University and National Research Council of Thailand for financial support for Grant no. 591904, Assoc.Prof. Thongchai Champasri, Department of Fisheries, Faculty of Agriculture, Khon Kean University and Asst. Prof. Apinun Suvarnaraksha, Faculty of Fisheries Technology and Aquatic Resources, Maejo University, Thailand, for fish identification. We thank Edanz Group (https://en-author-services.edanz group.com/ac) for English editing.

\section{Author contributions}

Designed and wrote the manuscript (C.C.), performed SDS-PAGE, zymography, enzyme stability, constructed the graphs and pictures, data analysis (C.C.), collected the sample, enzyme extraction, determined $\mathrm{pH}$ and temperature optimum (S.P. and C.P.). All authors reviewed and approved the manuscript. 


\section{Competing interests}

The authors declare no competing interests.

\section{Additional information}

Supplementary Information The online version contains supplementary material available at https://doi. org/10.1038/s41598-021-85258-7.

Correspondence and requests for materials should be addressed to C.C.

Reprints and permissions information is available at www.nature.com/reprints.

Publisher's note Springer Nature remains neutral with regard to jurisdictional claims in published maps and institutional affiliations.

(c) (1) Open Access This article is licensed under a Creative Commons Attribution 4.0 International License, which permits use, sharing, adaptation, distribution and reproduction in any medium or format, as long as you give appropriate credit to the original author(s) and the source, provide a link to the Creative Commons licence, and indicate if changes were made. The images or other third party material in this article are included in the article's Creative Commons licence, unless indicated otherwise in a credit line to the material. If material is not included in the article's Creative Commons licence and your intended use is not permitted by statutory regulation or exceeds the permitted use, you will need to obtain permission directly from the copyright holder. To view a copy of this licence, visit http://creativecommons.org/licenses/by/4.0/.

(c) The Author(s) 2021 